\title{
Cerebellar Granule Cell Migration and the Effects of Alcohol
}

\author{
Yulan Jiang ${ }^{a}$ Tatsuro Kumada $^{a}$ D. Bryant Cameron ${ }^{a}$ Hitoshi Komuro a, b

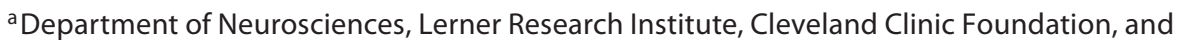 \\ ${ }^{b}$ Department of Molecular Medicine, Cleveland Clinic Lerner College of Medicine of Case Western \\ Reserve University, Cleveland, Ohio, USA
}

\section{Key Words}

Cerebellar granule cell $\cdot$ Neuronal migration .

Fetal alcohol syndrome $\cdot \mathrm{Ca}^{2+}$ signaling $\cdot \mathrm{CAMP}$ signaling • cGMP signaling $\cdot$ Early postnatal mouse cerebellum

\begin{abstract}
In the developing brain the majority of neurons migrate from their birthplace to their final destination. This active movement is essential for the formation of cortical layers and nuclei. The impairment of migration does not affect the viability of neurons but often results in abnormal differentiation. The proper migration of neurons requires the orchestrated activities of multiple cellular and molecular events, such as pathway selection, the activation of specific receptors and channels, and the assembly and disassembly of cytoskeletal components. The migration of neurons is very vulnerable to exposure to environmental toxins, such as alcohol. In this article, we will focus on recent developments in the migration of cerebellar granule cells. First, we will describe when, where and how granule cells migrate through different cortical layers to reach their final destination. Second, we will present how internal programs control the sequential changes in granule cell migration. Third, we will review the roles of external guidance cues and transmembrane signals in granule cell migration. Finally, we will reveal mechanisms by which alcohol exposure impairs granule cell migration.

Copyright $\odot 2008$ S. Karger AG, Basel
\end{abstract}

\section{Introduction}

The migration of postmitotic neurons from their sites of origin to their final destinations, where they make synaptic connections, is a fundamental cellular event essential for building large neuronal assemblies [1-3]. For example, the embryonic cerebrum displays 2 distinctive patterns of neuronal migration. Projecting neurons are primarily generated in the ventricular zone and then migrate to the developing cortical plate by means of radial migration [4-6]. In contrast, most GABAergic interneurons originate in the medial ganglionic eminence of the ventral telencephalon and follow tangential migratory routes through the intermediate zone and marginal zone to reach the cortical plate $[7,8]$. In humans, distinct genetic mutations and environmental toxins can affect neuronal migration and result in abnormal cortical development [9-11]. Although it is still unclear how these cortical abnormalities develop, accumulated evidence has begun to indicate that the migration of neurons is controlled by the orchestrated activities of multiple molecular events [12-14]. These include the response to repulsive and attractive signals and the alterations of the second messenger signaling pathways $[15,16]$.

This review is based on studies of the migration of cerebellar granule cells. The prenatal and early postnatal cerebellum has been used as a model system for neuronal migration because the defined neuronal cytoarchitecture

\section{KARGER}

(C) 2008 S. Karger AG, Basel

Fax +4161306 1234

E-Mail karger@karger.ch

www.karger.com
Accessible online at: www.karger.com/dne
Dr. Hitoshi Komuro

Department of Neurosciences/NC30, Lerner Research Institute

The Cleveland Clinic Foundation, 9500 Euclid Avenue

Cleveland, OH 44195 (USA)

Tel. +1 216444 4497, Fax +1 216444 7927, E-Mail komuroh@ccf.org 
and the small number of neuronal types in the cerebellum provide an ideal system for determining cellular and molecular mechanisms of neuronal migration [17, 18]. Specifically, the migration of granule cells has been intensively examined, and it has become apparent that the mechanisms underlying granule cell migration are utilized during the migration of immature neurons in other brain regions [2, 3, 15-17]. For example, the role of neuron-glia interaction in neuronal migration was first discovered in migrating granule cells and Bergmann glial cells in the developing cerebellum [19]. Thereafter, it has become apparent that in the developing cerebrum, immature neurons also use the processes of radial glia as a scaffold for their migration towards the cortical plate [20]. Furthermore, the role of cell adhesion molecules in neuronal migration was determined first in granule cell migration [21-24]. Later, wide varieties of cell adhesion molecules, which play a critical role in neuronal migration, were identified in the developing brain, including the cerebrum $[2,14,17]$. Moreover, the control of neuronal migration by neurotransmitters was first discovered in granule cells as a regulation of their migration by glutamate [25]. Thereafter, the role of not only glutamate but also $\gamma$-aminobutyric acid was discovered in the migration of cortical neurons in the developing cerebrum [26-28].

During the past decade, the use of cerebellar slices from early postnatal mice in conjunction with confocal microscopy and fluorescent lipophilic carbocyanine dyes revealed how granule cells migrate through the different cortical layers of the developing cerebellum and determined how an identified granule cell attains its final destination [29-31]. Furthermore, the varieties of extracellular and intracellular signals that regulate granule cell migration were discovered $[15,16]$. Most recently, the cellular and molecular mechanisms by which alcohol impairs granule cell migration in a mouse model of fetal alcohol syndrome (FAS) were determined [32].

In this article, we will first describe the cortical-layerspecific changes in granule cell migration in the early postnatal mouse cerebellum. Second, we will reveal the internal programs which control the sequential changes in granule cell migration in vitro. Third, we will cover the extracellular molecules and intracellular signals that regulate granule cell migration. Finally, we will discuss the latest developments in the study of how alcohol impairs granule cell migration.

\section{Cortical-Layer-Specific Changes in Granule Cell Migration in the Early Postnatal Cerebellum}

Granule cells alter the mode, tempo and direction of migration as they traverse different cortical layers of the cerebellum (as schematically presented in fig. 1a) [29-31]. In this section, we will describe granule cell migration layer by layer in the early postnatal mouse cerebellum.

\section{The External Granular Layer}

At the top of the external granular layer (EGL), granule cell precursors proliferate every $18-20 \mathrm{~h}$ [31]. After final mitosis, granule cells remain in the EGL for 24$48 \mathrm{~h}$ before initiating their radial migration across the molecular layer (ML) [31, 33]. During this latent period the cells tangentially migrate within the middle and bottom of the EGL [31]. In the middle of the EGL, coinciding with the extension of 2 uneven horizontal processes oriented parallel to the longitudinal axis of the folium, the cells start to migrate tangentially in the direction of the larger process [31]. Their morphology and speed of movement change systematically with their position within the EGL [31]. The rate of movement is fastest $(\sim 14.8$ $\mu \mathrm{m} / \mathrm{h}$ ) in the middle of the EGL, when the cells have 2 short horizontal processes. As the cells elongate their somata and extend longer horizontal processes at the bottom of the EGL, they move at a reduced rate $(\sim 12.6 \mu \mathrm{m} / \mathrm{h})$. At the interface of the EGL and the ML, where the cells migrate at the slowest rate $(\sim 4.1 \mu \mathrm{m} / \mathrm{h})$, their somata round and then begin to extend couples of descending processes into the ML. After the stationary period, the cells abruptly extend a single vertical process and initiate the transition from tangential to radial migration, reshaping their rounded somata into a vertically elongated spindle [31].

\section{The $M L$}

In the ML, the granule cells have vertically elongated cell bodies, thin trailing processes, and more voluminous leading processes, and migrate radially along the Bergmann glial processes [19]. In this layer, the rates of granule cell movement depend critically on the age of the cerebellum [29]. The average rate of migration in the ML increases systematically from $9.6 \mu \mathrm{m} / \mathrm{h}$ in P7 to 18.0 $\mu \mathrm{m} / \mathrm{h}$ in P13. Consequently, the cells traverse the developing ML within a relatively constant time period (10$11 \mathrm{~h}$ ) despite the doubling in width of the layer during the second week of postnatal life $[29,30]$. The movement of the cells in this layer is characterized by alternations of short stationary phases with movement in a forward or 
Fig. 1. Alterations of the mode and direction of granule cell migration in vivo and in vitro. a Three-dimensional representation of granule cell migration from the external granular layer (EGL) to the internal granular layer (IGL) in the early postnatal mouse cerebellum. 1 = Tangential migration in the middle and bottom of the EGL; 2 = Bergmann-glia-guided radial migration in the molecular layer (ML); 3 = stationary state in the Purkinje cell layer (PCL); 4 = glia-independent radial migration in the IGL; 5 = completion of migration in the middle or the bottom of the IGL; P = Purkinje cell; $\mathrm{B}=$ Bergmann glia; $\mathrm{G}=$ Golgi cell; $\mathrm{g}=$ postmigratory granule cell; $\mathrm{mft}=$ mossy fiber terminal. b Schematic representation of sequential changes in granule cell morphology and modes of turning in vitro. Isolated granule cells go through 3 characteristic changes in their migration and morphology without cellcell contact. The first phase (PI) is a period of $0-20 \mathrm{~h}$ in vitro, when granule cells initiate their migration. The second phase II (PII) is a period of $20-40 \mathrm{~h}$ in vitro, when granule cells have their long leading processes and move at the fastest rate. The third phase III (PIII) is a period of 40$60 \mathrm{~h}$ in vitro, when granule cells terminate their migration. Asterisks indicate first images of granule cells taken during each series of observation. A circle indicates a postmigratory granule cell in the late stage of PIII. Pseudocolor images represent the images of the granule cells, which were taken approximately every $30 \mathrm{~min}$.
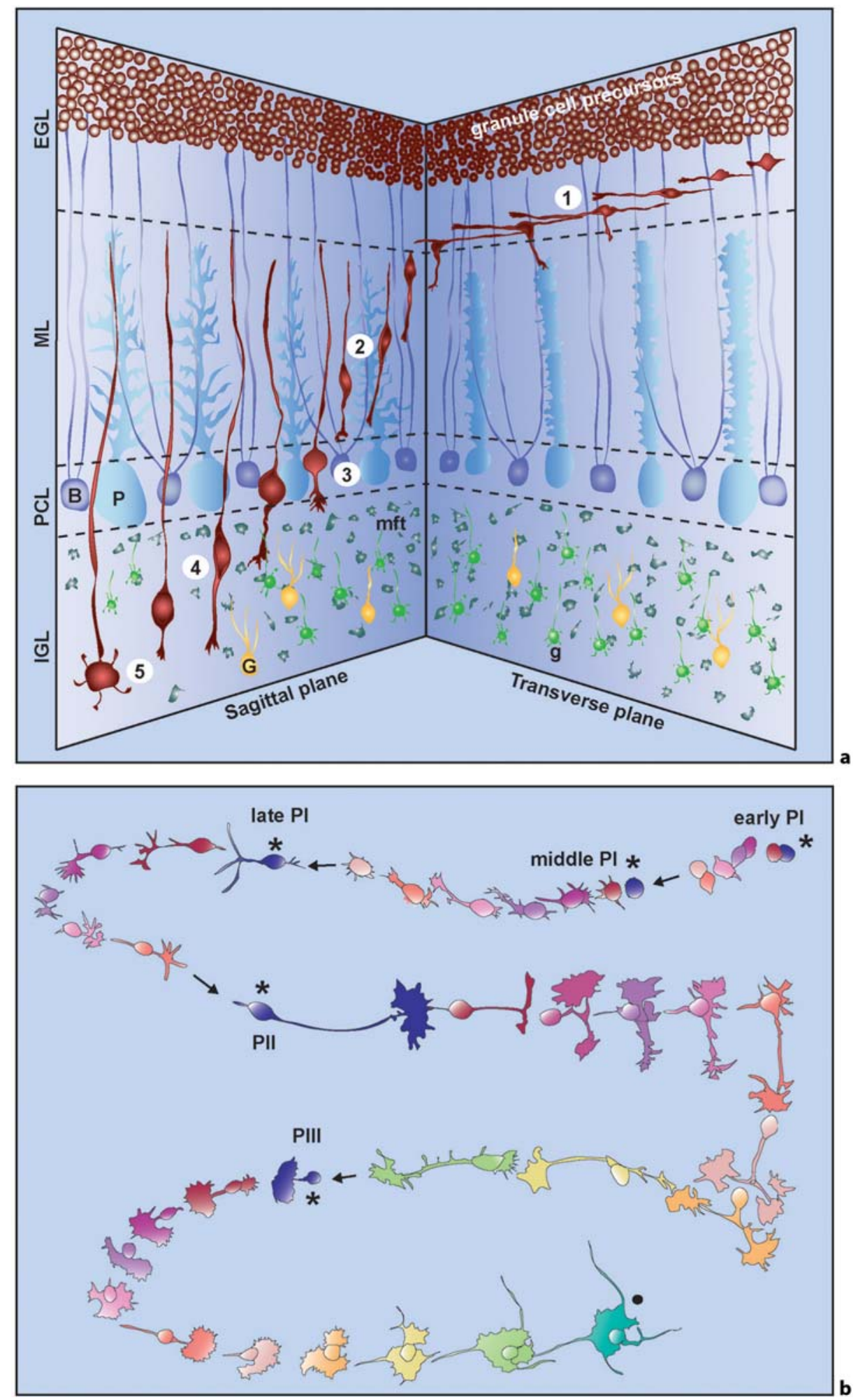
backward direction [29]. The net displacement of the cells depends on the duration and frequency of these phases as well as on the speed of movement [29].

\section{The Purkinje Cell Layer}

Upon entering the Purkinje cell layer (PCL), the granule cells detach from the processes of the Bergmann glial cells, and the shape of their cell bodies abruptly transforms from a vertically elongated spindle to a sphere [30]. The rounded somata significantly slow their movement and stop completely in the PCL [30]. The somata remain stationary in the PCL for an average of $115 \mathrm{~min}$, with times ranging from 30 to $220 \mathrm{~min}$ [30]. However, highly motile lamellipodia and filopodia develop at the distal portion of the leading process, suggesting that the tips of leading processes actively search for potential guidance cues. After a prolonged stationary period, the cells in the PCL begin to re-extend their somata and leading processes. During this transformation, the cells gradually accelerate the rate of migration and cross the border between the PCL and the internal granular layer (IGL) [30].

\section{The IGL}

In this layer, the granule cells migrate radially towards the bottom of the IGL without an association of glial cells at a rate comparable to that observed in the ML [30]. The long axis of their somata remains oriented perpendicularly to the PCL-IGL boundary line during this radial migration. Interestingly, once the tip of a leading process approaches the IGL-white-matter border, their somata become rounded again [30]. Thereafter, the cells gradually slow their migration and stop movement near the IGL-white-matter border [30]. In early postnatal mouse cerebella, the majority of granule cells complete their migration at the bottom stratum of the IGL.

In vitro studies with the use of real-time observation of granule cell migration in acute cerebellar slices revealed that in the P10 mouse cerebellum, the granule cells first move tangentially about $220 \mu \mathrm{m}$ in the EGL and then migrate radially about $250 \mu \mathrm{m}$ to reach their final position in the IGL $[29,30]$. The average transit time of granule cells is $25.0 \mathrm{~h}$ in the EGL, $9.8 \mathrm{~h}$ in the ML, $5.2 \mathrm{~h}$ in the PCL and $11.1 \mathrm{~h}$ to attain their final position in the IGL [29-31]. Therefore, granule cells move from the top of the EGL through the ML and the PCL to their final position in the IGL within about 2 days (average $=51 \mathrm{~h}$ ) [29-31].

\section{Comparison of Cerebellar Granule Cell Migration in the Studies Using in vivo and in vitro Models}

In vivo analysis of granule cell migration using ${ }^{3} \mathrm{H}$ thymidine autoradiography revealed that in P10 mice, granule cell precursors occupy the top half of the EGL and actively proliferate [33-35]. After final mitosis, granule cells translocate to the bottom half of the EGL and stay there for approximately 20-30 h [36]. Thereafter, granule cells migrate through the ML and the PCL to the IGL. The entire population of the granule cells in the IGL arises postnatally in the EGL between P1 and P18, and $95 \%$ of the granule cells in the IGL are produced between P4 and P15 [36]. Based on the observation of changes in the position of ${ }^{3} \mathrm{H}$-thymidine-labeled granule cells in the cerebellar cortical layers after an injection of ${ }^{3} \mathrm{H}$-thymidine, Fujita et al. [36] estimated that the transit times of the granule cells migrating across the EGL and the ML of P10 mice are approximately 21 and $4 \mathrm{~h}$, respectively. The estimated transient time of granule cells in the EGL and the ML in vitro studies is shorter than that obtained in the in vivo studies. This difference may result from the wide range $(20-48 \mathrm{~h})$ in the period of time required for granule cells to initiate their radial migration into the ML after final cell division [31, 33].

Recently, studies with the use of 5-bromo-2'-deoxyuridine (BrdU) showed the time course of the translocation of cerebellar granule cells in early postnatal mice after their final mitosis [31]. P10 mice were injected with BrdU and then sacrificed 2, 24 and $48 \mathrm{~h}$ later. Two hours after injection, BrdU-labeled cells were localized at the outermost 2 rows of the EGL, indicating that granule cell precursors proliferate within the top level of the EGL, while the middle and bottom levels of the EGL contain unlabeled postmitotic granule cells [31]. Within the following $24 \mathrm{~h}$, the BrdU-labeled cells spread across the entire EGL, and some begin their descent to the ML [31]. Forty-eight hours after BrdU injection, approximately $50 \%$ of the BrdU-labeled granule cells left the EGL and translocated their soma into the ML, PCL or IGL. This suggests that within $48 \mathrm{~h}$ after final mitosis, many postmitotic granule cells begin to migrate radially towards the IGL, and some of them have already reached their final destinations in the IGL [31]. It has been shown that the postsynthetic phase and the mitotic phase of the granule cell precursor's cycle in 10-day-old mouse cerebella last 2 and $0.5 \mathrm{~h}$, respectively [33]. Taken together, these results demonstrate that in the early postnatal cerebellum, granule cells are able to attain their final destination in the IGL approximately $46 \mathrm{~h}$ after their final mitosis. 
Interestingly, the estimated time required for granule cells to reach their final migration in vivo is similar to that obtained from the studies using acute cerebellar slice preparations.

Although radial migration of granule cells along the Bergmann glial processes in the ML has been extensively analyzed using in vivo models, little is known about the early behavior of postmitotic granule cells within the EGL before they start their descent to the ML. A major impediment in the analysis of granule cell behavior in the EGL was the availability of a reliable assay system. For example, the use of ${ }^{3} \mathrm{H}$-thymidine labeling alone could not reveal the extent, direction and rate of cell migration within a histologically homogeneous cell layer such as the EGL. The use of replication-incompetent retrovirus suggests that granule cells may migrate tangentially in both rostrocaudal and mediolateral planes before the onset of the radial migration [37]. The in vitro studies of granule cell behavior directly demonstrated that, at the various levels of the EGL, postmitotic granule cells exhibit a different morphology and rate of tangential movement before the onset of radial migration.

\section{Intrinsic Programs for Controlling Sequential Changes in Granule Cell Migration}

As described above, granule cells exhibit a distinct mode and tempo of migration in the different cortical layers of the cerebellum. Although such changes in the migration are likely to be induced by responses to local environmental cues, the alterations may also depend, at least in part, on an internal clock or intrinsic programs. This is because in the microexplant cultures of early postnatal mouse cerebella, granule cells sequentially go through 3 characteristic phases of migration and morphology without cell-cell contact, suggesting that inherent (intrinsic) mechanisms control the alterations of their migration and morphology [38]. The three sequential changes in the migration and morphology of granule cells in the cerebellar microexplant cultures are as follows:

\section{The First Phase (a Period of 0-20 h in vitro)}

At the early stage of the first phase (PI), the granule cells repeatedly change the shape of their somata from spherical to spindle and vice versa [38]. The cells frequently turn to the left or right without extending leading processes (as illustrated in fig. 1b). At the point at which the cells change their direction of movement, they stop movement, become round and then extend their somata in the direction of the upcoming movement. Shortly after the extension, the cells resume their movement parallel to the direction of the longitudinal axis of the cell bodies. At the middle stage of PI, the cells repeatedly extend and withdraw short leading processes and move at a fast rate only after the process fully extends [38]. The extension of a new leading process towards a different direction is an essential prerequisite for changing the direction of cell movement. At the end of PI, the cells start to develop a new mode of turning behavior; first, the tip of the leading process turns in a new direction, and then the cell body follows the changes [38].

\section{The Second Phase (a Period of 20-40 h in vitro)}

At the early stage of the second phase (PII), the granule cells develop another mode of turning behavior as follows: (a) the tip of leading process bifurcates; (b) both branches extend in the opposite direction; (c) one of the branches collapses and retracts, and (d) the cell body follows the direction of extension of the remaining branch [38]. The cells exhibit this mode of turning behavior throughout PII. At the late stage of PII, the cells often become stationary for $2-3 \mathrm{~h}$ and retract their processes [38].

\section{The Third Phase (a Period of 40-60 h in vitro)}

At the early stage of the third phase (PIII) the granule cells start to exhibit characteristic changes in their leading process, which are the initial signs of the termination of their migration [38]. At the late stage of PIII, the cells gradually slow down their movement. At the end the cells become permanently stationary, extend a lamellipodium around the soma and emit several thin processes [38]. In the microexplant cultures of early postnatal mouse cerebella, the majority of granule cells terminate their migration $50-60 \mathrm{~h}$ after the initiation of their movement without external cues [38]. Interestingly, this 50 - to 60 hour term of granule cell migration is comparable to the time required for granule cells to migrate from the EGL to the IGL in vivo $[15,16]$.

Several features of granule cell migration also systematically change as the elapsed time goes on after an initiation of cultures, indicating intrinsic programs for cell migration [38]. For example, in PI, the cells migrate at an average rate of $26.0 \mu \mathrm{m} / \mathrm{h}$, which is determined by dividing the total traveling distance by the period of the observation, and exhibit the highest rate of turning behavior (1.3 turns/h) when the cells have multiple (3.7 processes/ cell) and short $(20.8 \mu \mathrm{m})$ processes [38]. The length of the 
cycle of cell movement and stationary state is shortest $(218$ min). In PII, the cells extend a long and thick process (55.6 $\mu \mathrm{m})$, and exhibit an elongated cycle $(244 \mathrm{~min})$ of cell movement and stationary state. The rate of cell movement is fastest $(33.1 \mu \mathrm{m} / \mathrm{h})$, while the rate of turning is lowest ( 0.3 turn/h). In PIII, the cells decrease the rate of the movement $(25.2 \mu \mathrm{m} / \mathrm{h})$ but slightly increase the turning rate $(0.5 \mathrm{turn} / \mathrm{h})$. The length of the cycle of cell movement further increases to $297 \mathrm{~min}$. There is a statistical significance $(\mathrm{p}<0.01)$ in the average rate of granule cell migration (1) between PI and PII and (2) between PII and PIII [38].

There is also other evidence suggesting that intrinsic programs control the changes in granule cell migration. For example, granule cells isolated from different postnatal stages also undergo the same patterns of changes in migratory behavior [38]. Furthermore, the majority of granule cells, which migrate on different concentrations and types of extracellular matrix molecules, exhibit the same patterns of changes during the migration in isolation as follows: (1) the rate of cell movement in PII is fastest; (2) the rate of turning behavior in PI is highest; (3) the length of cycle of cell movement systematically increases as time in vitro increases; (4) the length of the stationary state in PII is longest; (5) the number of processes in PI is largest, and (6) the length of the process in PIII is longest [38]. These results demonstrate the existence of intrinsic (inherent) programs for controlling granule cell migration in an age-dependent manner (or a developmentalstage-dependent manner).

\section{Mechanisms and Molecules of Controlling Granule Cell Migration}

To date, large numbers of molecules and genes have been discovered as potential regulators or modulators of neuronal cell migration. In this section, we will review signaling molecules and genes which play crucial roles in controlling granule cell migration.

\section{$\mathrm{Ca}^{2+}$ Channels and $\mathrm{Ca}^{2+}$ Signaling}

The activity of voltage-gated $\mathrm{Ca}^{2+}$ channels, especially the $\mathrm{N}$-type $\mathrm{Ca}^{2+}$ channel, plays a role in granule cell migration in the early postnatal mouse cerebellum $[39,40]$. The granule cells in the EGL start to express $\mathrm{N}$-type $\mathrm{Ca}^{2+}$ channels prior to the initiation of migration [39]. The number of $\mathrm{N}$-type $\mathrm{Ca}^{2+}$ channels expressed on the plasmalemmal surface of the cells rapidly increases during migration [39]. The blockade of $\mathrm{N}$-type $\mathrm{Ca}^{2+}$ channel activity significantly slows down granule cell migration, suggesting that the activity of $\mathrm{N}$-type $\mathrm{Ca}^{2+}$ channels is required for migration [39]. Interestingly, granule cells exhibit distinct frequencies of transient $\mathrm{Ca}^{2+}$ elevations as they migrate in different cortical layers and complete migration only after the loss of $\mathrm{Ca}^{2+}$ elevations [41]. There is a positive correlation between the rate of migration and the frequency of $\mathrm{Ca}^{2+}$ elevations [40,41]. The reduction of the frequency of $\mathrm{Ca}^{2+}$ elevations halts granule cell migration prematurely, while increasing the frequency significantly delays the completion of migration [41]. The timing of the loss of $\mathrm{Ca}^{2+}$ elevations is intrinsically set in the granule cells and influenced by external cues [41]. The results suggest that $\mathrm{Ca}^{2+}$ signaling functions as a mediator for controlling granule cell migration.

\section{N-Methyl-D-Aspartate Subtype of Glutamate \\ Receptors}

The presence of spontaneous activity of the NMDA (N-methyl-D-aspartate) receptors on the surface of migrating granule cells has been confirmed by patch-clamp analysis [42]. Migrating granule cells coexpress the NR1 and NR2A or NR2B subunits of NMDA receptors, whereas postmigratory granule cells in the IGL express the NR1 and NR2C types $[43,44]$. Importantly, blocking NMDA receptor activity significantly decreases the rate of granule cell movement [25], whereas stimulating NMDA receptor activity significantly increases the rate [32]. Furthermore, the elevation of extracellular glutamate concentrations by inhibiting glutamate uptake by astrocytes increases the frequency of spontaneous NMDA-receptorcoupled channel activity and significantly accelerates the rate of granule cell migration [25]. Endogenous extracellular glutamate could control granule cell migration through activation of the NMDA receptors by nonsynaptic means because the cells do not form synapses before the completion of migration [25].

\section{Brain-Derived Neurotrophic Factor}

Granule cells express brain-derived neurotrophic factor (BDNF) and its high-affinity receptor (TrkB) [45, 46]. The level of BDNF expression increases during early postnatal development $[45,46]$. Interestingly, in $\mathrm{BDNF}^{-/-}$ mice granule cells exhibit impaired migration, and the application of BDNF stimulates movement [47].

\section{Neurotrophin-3}

Neurotrophin-3 (NT-3) mRNA expression begins with the emergence of the EGL in the prenatal cerebellum and significantly increases between P5 and P20 [48, 49]. Granule cells in the EGL express the NT-3 receptor (TrkC) 
before the initiation of migration [50]. Chronic application of exogenous NT-3 results in a significant reduction of the thickness of the EGL without cell death, suggesting that NT-3 accelerates the exit of granule cells from the EGL [51].

\section{Neuregulin}

Granule cells express neuregulin (NRG), and glial cells express its receptor, erbB4 [52]. Blockade of the glial erbB4 receptors impairs granule cell migration along the glial fibers, indicating that NRG and erbB 4 are essential for glia-associated migration of granule cells in the ML [52].

\section{Stromal-Cell-Derived Factor $1 \alpha$}

Stromal-cell-derived factor $1 \alpha(\mathrm{SDF}-1 \alpha)$ expression is present in the pial membrane, while granule cell precursors express its receptor CXCR4 $[53,54]$. In the SDF- $1 \alpha-$ or CXCR4-deficient mice, granule cell precursors prematurely migrate away from the EGL and locate ectopically outside the EGL $[53,55]$. SDF- $1 \alpha$ induces chemotactic responses in granule cell precursors [56]. These results suggest that SDF- $1 \alpha$ and CXCR4 play a crucial role in retaining granule cell precursors in the EGL by chemoattracting toward the pia mater.

\section{Ephrin-B2}

Ephrin-B2 and its receptor, EphB2, are expressed in the EGL of the early postnatal mouse cerebellum [57]. Interestingly, the chemoattractant effect of SDF- $1 \alpha$ to the granule cells is selectively inhibited by soluble EphB2 receptor through reverse signaling of ephrin-B2 [57]. These results suggest that when granule cells are ready to migrate out from the EGL, they lose responsiveness to SDF$1 \alpha[57]$.

\section{Astrotactin}

Astrotactin null mice show a decrease in granule cell binding to the glial cells and a reduction in the rate of granule cell migration [58]. This suggests that astrotactin functions in granule cell migration along glial processes in the ML.

\section{Tenascin}

Tenascin, an extracellular matrix molecule, influences the migration of granule cells along the Bergmann glial processes through different domains in the fibronectin type III homologous repeats [59].

Alcohol Action on Granule Cell

Migration

\section{Tissue Plasminogen Activator}

Granule cells turn on the gene for tissue plasminogen activator (tPA) as they begin their migration into the ML [60]. The cells both secrete TPA and bind tPA to their cell surface. Interestingly, $\mathrm{tPA}^{-1-}$ mice have $>2$-fold more migrating granule cells in the ML [61]. In vitro assays reveal that granule cells in $\mathrm{tPA}^{-/}$mice migrate through the $\mathrm{ML}$ at about half the rate measured in $\mathrm{tPA}^{+/+}$mice [62]. This suggests that tPA gene expression is required for maintaining the maximal rate of granule cell migration.

\section{Platelet-Activating Factor}

Platelet-activating factor (PAF) has been implicated in the human neuronal migration disorder Miller-Dieker lissencephaly $[63,64]$. In this disorder, the brain has a smooth cortical surface (lissencephaly) caused by a lack of complexity of the outer cortex, and the migration of cerebellar granule cells is disrupted [63-65]. The malformation of the brain results from a haploinsufficiency of the gene LIS-1, which encodes a $45-\mathrm{kDa}$ subunit of the brain PAF acetylhydrolase, an enzyme that converts PAF into the inactive lyso-PAF by removing the acetyl group on the $s n 2$ position of the PAF molecule [66-68]. PAF receptor activation evokes changes in the cytoskeleton, which could lead to a disruption of neuronal migration [69]. Application of the nonhydrolyzable PAF receptor agonist yields a dose-dependent decrease in cerebellar granule cell migration [70].

\section{Cyclin-Dependent Kinase 5}

Cyclin-dependent kinase 5 (Cdk-5) is a unique member of the cyclin-dependent kinases [71]. Unlike other cyclin-dependent kinases, Cdk-5 expression and kinase activity are not high during cell division. The appearance of active Cdk- 5 is correlated with the cessation of neurogenesis and the beginning of differentiation of neuronal cells [72]. In the cerebella of $c d k 5^{-/-}-c d k 5^{+/+}$mice, significant numbers of granule cells are located in the ML, suggesting a failure to complete migration to the IGL [73]. The cells found within the ML of chimeric cerebella are nearly all Cdk5-deficient, while the cells within the IGL are a mixture of $c d k 5^{-/}$and $c d k 5^{+/+}$cells [73]. These results suggest that Cdk-5 plays crucial roles in the execution of granule cell migration.

\section{9-O-Acetyl GD3}

9-O-acetyl GD3, a ganglioside, is expressed in the developing nervous system [74]. Interestingly, 9-O-acetyl GD3 is localized at the contact sites between migrating granule cells and Bergmann glial processes in the ML 
[74]. Application of Jones monoclonal antibody, which recognizes 9-O-acetyl GD3, blocks granule cell migration in a dose-dependent manner [74]. These results suggest that 9-O-acetyl GD3 is involved in Bergmann-gliaassociated migration of granule cells in the ML.

\section{Somatostatin}

Somatostatin (STT), a neuropeptide, has 2 bioactive products, somatostatin-14 (SST-14) and somatostatin-28 (SST-28), which bind to all 5 somatostatin receptors [75, 76]. Granule cells express all 5 types of SST receptor before an initiation of migration, while differentiated granule cells in the adult do not express the receptors [77]. High levels of SST-14 are present in Purkinje cells, Golgi cells and climbing fibers, and SST-28 is present in Golgi cells and mossy fiber terminals [78, 79]. Application of SST-14 or SST-28 significantly increases the rate of granule cell movement in the EGL, slightly decreases the rate in the ML and significantly decreases the rate in the IGL [79]. In contrast, an STT antagonist, AC-178,335, significantly decreases the rate of granule cell migration in the EGL, slightly increases the rate in the ML and significantly increases the rate in the IGL [79]. These results indicate that endogenous STT differentially controls the migration of granule cells in a cortical-layer-specific manner: STT accelerates the tangential migration of granule cells near their birthplace within the EGL but slows down radial movement near their final destination within the IGL.

In the above sections, we described the multiple molecules that have been identified as critical regulators for granule cell migration. Although these molecules affect granule cell migration through activating or inhibiting the wide varieties of downstream targets, there are 3 common signaling pathways $\left[\mathrm{Ca}^{2+}\right.$ signaling, cyclic nucleotide signaling and mitogen-activated protein kinase (MAPK) signaling], which may play central roles in controlling granule cell migration. The role of the $\mathrm{Ca}^{2+}$ signaling pathway in granule cell migration is supported by the evidence that the activation of $\mathrm{N}$-type $\mathrm{Ca}^{2+}$ channels and NMDA receptors increases the frequency of spontaneous elevations of intracellular $\mathrm{Ca}^{2+}$ levels in migrating granule cell somata by stimulating the $\mathrm{Ca}^{2+}$ influxes, leading to the acceleration of migration $[25,39,40]$. PAF and SDF- $1 \alpha$ induce intracellular $\mathrm{Ca}^{2+}$ mobilization, which stimulates granule cell migration [80-82]. Furthermore, tPA indirectly modulates the $\mathrm{Ca}^{2+}$ signaling pathway by enhancing the activity of NMDA receptors [83]. Interestingly, SST regulates the frequency of $\mathrm{Ca}^{2+}$ transients in the somata of migrating granule cells in a cortical-layer-specific manner [79]. Application of SST increases the frequency of $\mathrm{Ca}^{2+}$ transients in the migrating granule cells near their birthplace but decreases the frequency near their final destination [79]. Collectively, these results suggest that the $\mathrm{Ca}^{2+}$ signaling pathway plays a key role in converting the extracellular guidance signals to intracellular signals, which are responsible for controlling granule cell migration.

Cyclic nucleotide signaling pathways, including cyclic AMP (cAMP) and cyclic GMP (cGMP), are also potential downstream targets for controlling granule cell migration. For example, the activation of NMDA receptors increases intracellular cGMP levels through the sequential stimulation of the following systems: nitric oxide synthase-nitric oxide-soluble guanylyl cyclase-cGMP [84]. tPA may increase the production of cGMP by stimulating the activity of NMDA receptors [83]. Furthermore, PAF increases intracellular concentrations of cAMP via the activation of adenylate cyclase (AC) [80]. In contrast, SST decreases intracellular cAMP levels by inhibiting AC activity via stimulating the $\mathrm{Gi}$ subunit of $\mathrm{G} \alpha$-coupled receptors [85]. Recently, it was reported that the rate of granule cell migration is very sensitive to changes in the intracellular levels of cGMP and cAMP [32]. Therefore, it is possible that NMDA receptors, $\mathrm{TPA}, \mathrm{PAF}$ and SST control granule cell migration by altering the cyclic nucleotide signaling pathways.

MAPK signaling is another potential target for extracellular- and intracellular-signal-induced alterations of granule cell migration. For example, BDNF and NT-3 stimulate MAPK through the activation of TrkB and TrkC receptors [86-88]. SDF-1 $\alpha$ increases the phosphorylation of extracellular-signal-regulated kinases 1 and 2 (ERK1/2) via the activation of CXCR4 receptors [82]. Furthermore, Cdk5 regulates MAPK kinase $1 / 2$ activity [89]. Importantly, the inhibition of MAPK activity by specific inhibitors significantly reduces the rate of granule cell migration [32]. Taken together, these results indicate that MAPK signaling pathways play a key role in the regulation of granule cell migration by BDNF, NT-3, SDF- $1 \alpha$ and Cdk5.

In the following sections we will review the studies examining how alcohol exposure causes abnormal development of the brain and mechanisms by which alcohol exposure impairs granule cell migration. 


\section{Effects of Alcohol on Brain Development}

Alcohol is presently the most common chemical teratogen causing malformation and mental deficiency in humans $[90,91]$. Prolonged exposure to alcohol during gestation and lactation correlates with a pattern of abnormal development in newborns [90-92]. Jones and Smith [93] called this developmental disturbance 'fetal alcohol syndrome' (FAS). Maternal exposure to alcohol may not lead to full expression of FAS but rather may result in a variety of less pronounced dysmorphic, cognitive and behavioral effects, often termed 'fetal alcohol effects (FAE)' $[90,91]$. The world incidence of FAS is estimated as approximately 1.9 per 1,000 live births, while the incidence of FAE is thought to be as high as 1 in 300 live births [94]. Overt FAS, a more clearly defined endpoint than FAE, is one of the most common causes of mental retardation worldwide. The clinical features of FAS are distinctive. A severe disturbance of growth is the hallmark of the disorder [90-92]. At birth the infants manifest a distinct pattern of growth retardation, with length affected more than weight. The growth deficiency persists postnatally, but weight gain becomes more disturbed than linear growth. Abnormalities of growth are not altered appreciably by attempts to change environmental variables such as nutritional factors, home setting and the like. The most serious feature of the syndrome is disturbance of the central nervous system $[90-93,95]$. Microcephaly is present in nearly all cases, and this reflection of disturbed brain growth is accompanied by delayed neurologic development in approximately $90 \%$ of the cases $[90,91,96]$. Particular defects of speech and language development are also evident [92]. In addition to serious cognitive deficits, a far-reaching and pervasive state of disability is induced by behavioral disturbances, impaired communication skills and maladaptive social function, manifested by lack of reciprocal friendships, impulsive behavior, anxiety and dysphoria. Children with FAS also show neurological signs associated with cerebellar damage such as delayed motor development, problems with fine tasks and ataxia [97, 98].

The fundamental mechanisms whereby alcohol leads to disturbances of brain development have not been elucidated. Current evidence favors the concept that alcohol or a metabolic product is responsible for the teratogenic effects expressed in FAS $[99,100]$. Alcohol rapidly crosses the placenta and the blood-brain barrier of the fetus. Data obtained from a variety of experimental models suggest that alcohol, or its metabolite, can adversely affect the developing brain through multiple mechanisms
$[99,100]$. These include direct effects such as transient impairment of uterine vessels and reduced fetal cerebral metabolic rate. Moreover, alcohol is also capable of adversely affecting DNA methylation, neurotransmitter receptors, signal transduction, trophic support of neurons and membrane fluidization [99-102].

\section{Abnormal Neuronal Migration in the Brains of FAS Patients}

Several aspects of the developmental program are involved in the alcohol-induced malformation of the brain [103]. Among them, the most striking abnormalities appear to involve the impairment of neuronal and glial migration $[104,105]$. The most common abnormality is a leptomeningeal neuroglial heterotopia that assumes the form of a sheet of aberrant neuronal and glial cells covering portions of the cerebral, cerebellar and brain stem surfaces [90]. Aberrations of brain stem and cerebellar development, in large part related to faulty cell migration, have also been especially frequent, along with the migrational disturbances of schizencephaly and polymicrogyria [106]. Disordered midline prosencephalic formation, e.g. agenesis of the corpus callosum, septo-optic dysplasia and incomplete holoprosencephaly, has also been documented [107]. Multiple aspects of central nervous system development can be affected, including proliferation, migration, differentiation and synapse formation.

\section{Animal Models for Studying FAS and FAE}

Pre- and/or neonatal exposure to alcohol also induces long-term neuromorphologic, neurochemical and behavioral changes in experimental animals [108, 109]. Some of these changes are observed in humans and thus led to the identification of FAS. In mice and rats, the early postnatal period is equivalent to fetal development in humans, and alcohol exposure causes a reduction of their brain weight, especially in the cerebellum [108-110]. The alcohol-exposed rats are hypoactive during treatment and exhibit a reduction in cerebellar Purkinje cell numbers, especially in the early maturing lobules [111]. Furthermore, the numbers of granule cells in the IGL are significantly reduced in the alcohol-treated animals [112], suggesting that alcohol affects granule cell migration to the IGL. Due to the obvious limitations of human studies, animal models of FAS have been used to further docu- 
ment the phenomenon of alcohol-induced defects in brain development and to study underlying mechanisms.

\section{Previous Studies on the Effects of Alcohol on Neuronal Migration in the Brain other than the Cerebellum Using Animal Models}

Prenatal exposure of ethanol induced morphological defects in the rat cerebral cortex, including heterotopia and disorganized cortical architecture, suggesting abnormal migration [113]. In the rat cerebrum, prenatal ethanol exposure delays the migration of early generated neurons to the deep cortical layers by 2 days and the migration of late generated neurons to the upper cortical layers by 4-6 days [105]. Moreover, ethanol exposure also reduces the rate of neuronal migration in the rat cerebrum [114]. It has been suggested that a likely mechanism underlying alcohol-induced defects in neuronal migration is disrupted cell adhesion. Neuronal cell adhesion molecule (nCAM) and L1 mediate neuronal migration through homophilic binding and consequent activation of intracellular signaling cascades central to cytoskeleton reorganization [115]. Ethanol inhibits L1-L1-mediated cell adhesion by physically blocking L1-L1 homophilic binding [116]. Furthermore, ethanol increases nCAM protein expression in cortical neurons [117]. Interestingly, ethanol-induced increases in nCAM are noted on the surface of migrating cortical neurons [114]. It has been shown that ethanol exposure disrupts transforminggrowth-factor- $\beta$-mediated migration of cortical neurons [114].

\section{Alcohol Inhibits Granule Cell Migration in the Developing Cerebellum}

Recently, an important advancement was made in understanding the cellular and molecular mechanisms underlying ethanol-induced abnormal migration of cerebellar granule cells [32]. In the following sections, we examine how alcohol impairs granule cell migration in the developing cerebellum. To examine cellular and molecular mechanisms by which alcohol affects neuronal migration, the cerebellum of the early postnatal mouse is used as a model system, since the exposure to ethanol induces quantitative morphological changes in the rodent cerebellum $[111,112,118]$. Real-time observation of cell movement in cerebellar slices reveals that the administration of $100 \mathrm{mM}$ of ethanol immediately slows the tangential migration of granule cells in the EGL of P10 mice [32]. Pharmacologically relevant concentrations of ethanol are based on blood-ethanol concentrations attained by alcohol consumption in humans [119]. Since ethanol readily crosses the placental and blood-brain barriers, and diffuses rapidly into all aqueous compartments of the body, these levels would readily be found in cases of alcohol consumption during pregnancy [120]. The effects of ethanol on the rate of granule cell migration in the cerebellar slices obtained from P10 mice are dose-dependent [32]. Although $2.5 \mathrm{~mm}$ of ethanol fails to alter the rate of cell movement, $10 \mathrm{mM}$ of ethanol (equivalent to a blood ethanol level $<50 \mathrm{mg} / \mathrm{dl}$ ) significantly decreases the rate to $62 \%$ (EGL), $76 \%$ (ML) and $82 \%$ (IGL) of the control value. In the presence of $50 \mathrm{~mm}$ of ethanol, the rate is further reduced to $40 \%$ (EGL), 55\% (ML) and 62\% (IGL) of the controls. Finally, when $100 \mathrm{~mm}$ of ethanol is added, movement declines to $35 \%$ (EGL), 50\% (ML) and 56\% (IGL) of the control. It is noteworthy that the vulnerability of granule cells to ethanol exposure decreases as the cells migrate from the EGL to the IGL. The differential vulnerability suggests that the stage of differentiation (or maturation) is critical in producing the harmful effects of ethanol on granule cell migration.

Ethanol may alter the motility of granule cells directly, or indirectly by modifying the surrounding environment. For example, ethanol exposure affects the development and functions of glia, which in turn may alter granule cell motility [121]. To determine whether ethanol directly affects granule cell migration, microexplant cultures of $\mathrm{P} 0-\mathrm{P} 3$ mouse cerebella, in which isolated granule cells actively migrate in the absence of cell-cell contact, are used [38]. Application of ethanol at concentrations ranging from 25 to $200 \mathrm{mM}$ appreciably slows the movement of isolated granule cells [32]. The average rate of cell movement is reduced to $85 \%$ ( $25 \mathrm{mM}$ of ethanol), $71 \%$ (50 $\mathrm{mM}$ of ethanol), $63 \%$ (100 $\mathrm{mM}$ of ethanol) and $46 \%$ (200 $\mathrm{mM}$ of ethanol) of the control [32]. These results indicate that ethanol directly acts on granule cell migration in a dose-dependent manner.

\section{Calcium Signalings Play a Role in Alcohol Action on Migration}

How does alcohol slow the migration of granule cells? Although the effects of alcohol are initially believed to arise from alcohol-induced perturbations in the order of membrane lipids, the effects on membrane lipids are ac- 
tually quite small at clinically relevant concentrations [122]. However, even low levels of alcohol can modulate the functions of voltage-gated and ligand-gated $\mathrm{Ca}^{2+}$ channels by binding to a hydrophobic pocket on the proteins [123]. This suggests that alcohol may affect the intracellular $\mathrm{Ca}^{2+}$ levels of migrating granule cells. This is intriguing because granule cell migration is highly sensitive to changes in intracellular $\mathrm{Ca}^{2+}$ levels and $\mathrm{Ca}^{2+}$ signaling [18, 40, 41]. Indeed, the use of a $\mathrm{Ca}^{2+}$ indicator dye reveals that application of ethanol significantly decreases the frequency of spontaneous $\mathrm{Ca}^{2+}$ transients in the granule cell somata in a dose-dependent manner [32], suggesting that one of the cellular mechanisms underlying alcohol action on granule cell migration is the alteration of $\mathrm{Ca}^{2+}$ signaling.

If alcohol slows granule cell migration by inhibiting $\mathrm{Ca}^{2+}$ signaling, enhancing $\mathrm{Ca}^{2+}$ release from internal $\mathrm{Ca}^{2+}$ stores or $\mathrm{Ca}^{2+}$ influxes across the plasma membrane may alter alcohol action on granule cell migration. To test this, (a) caffeine, which increases internal $\mathrm{Ca}^{2+}$ release through the ryanodine receptors, and (b) NMDA, which induces $\mathrm{Ca}^{2+}$ influxes through the NMDA-type glutamate receptors, are applied with ethanol. Intoxicating levels of alcohol are known to reduce the activity of these receptors [124, 125]. Application of $1 \mathrm{mM}$ of caffeine or 30 $\mu \mathrm{M}$ of NMDA noticeably reduces the effects of 25-100 $\mathrm{mM}$ of ethanol on the rate of granule cell movement [32]. These results suggest that ethanol affects granule cell migration by altering multiple components of $\mathrm{Ca}^{2+}$ signaling.

\section{Changes in Cyclic Nucleotide Signaling Pathways Affect Alcohol Action on Migration}

Alcohol may also inhibit granule cell migration via altering cyclic nucleotide signaling pathways, such as those involving cAMP or cGMP. An intraperitoneal injection of ethanol $(5 \mathrm{~g} / \mathrm{kg}$ body weight) into P10 mice markedly increases cAMP levels but decreases cGMP levels in the cerebellum $1 \mathrm{~h}$ after injection [32]. Without ethanol, the stimulation of AC with forskolin, which is upstream of cAMP signaling, markedly reduces the rate of granule cell movement; however, the inhibition of protein kinase A (PKA) with PKI, which is downstream of cAMP signaling, markedly increases the migration rate [32]. Similarly, without ethanol, application of a competitive cAMP agonist, Sp-cAMPS, reduces the rate of granule cell migration, whereas a competitive cAMP antagonist, Rp-cAMPS, increases the rate. These results dem- onstrate that without ethanol, the stimulation of cAMP signaling slows down granule cell migration, whereas the inhibition of cAMP signaling accelerates migration. Importantly, the inhibition of PKA activity with PKI significantly reduces the effects of 25-50 mM of ethanol on the rate of granule cell migration but fails to change the action of $100 \mathrm{mM}$ of ethanol on the migration [32]. Application of Rp-cAMPS completely reverses the effects of $25-100 \mathrm{mM}$ of ethanol on the rate of granule cell migration [32]. Moreover, the inhibition of the activity of AC with 9CP-Ade significantly reduces the effects of $100 \mathrm{mM}$ of ethanol [32]. In contrast, the stimulation of the AC activity with forskolin significantly enhances the effects of $25 \mathrm{mM}$ of ethanol on the rate of granule cell migration. These results demonstrate that alcohol action on granule cell migration is highly sensitive to changes in the activity of cAMP signaling pathways: stimulating cAMP signaling amplifies alcohol action on granule cell migration, whereas inhibiting cAMP signaling reduces action. Because the application of alcohol increases cAMP levels, alcohol may slow granule cell migration by stimulating cAMP signaling pathways.

In the case of the cGMP signaling pathway, without ethanol, stimulating cGMP signaling with cGMP analogue, Br-cGMP, increases the rate of granule cell movement, whereas inhibiting cGMP signaling with cGMP antagonist, Rp-8-pCPT-cGMPS, decreases the rate [32]. Interestingly, application of Br-cGMP markedly reduces the effects of 25-100 $\mathrm{mM}$ of ethanol on granule cell migration [32]. In contrast, Rp-8-pCPT-cGMPS does not change ethanol action on granule cell migration [32]. These results demonstrate that cGMP signaling is also a target for the alcohol action on granule cell migration. Alcohol may slow granule cell migration by lowering the activity of cGMP signaling pathways.

If alcohol affects granule cell migration by altering the cAMP and cGMP signaling pathways, one mechanism controlling alcohol action might be the degradation of these cyclic nucleotides. Indeed, the alterations of the activity of cyclic nucleotide phosphodiesterases (PDE), which catalyze the hydrolysis of cAMP and/or cGMP, change alcohol action on granule cell migration [19]. For example, application of EHNA, a PDE2 inhibitor that blocks the cGMP-dependent cleavage of cAMP and cGMP, significantly reduces ethanol action on granule cell migration [32]. In contrast, 8-MM-IBMX, a PDE1 inhibitor that blocks the $\mathrm{Ca}^{2+} /$ calmodulin-dependent cleavage of cAMP and cGMP, does not significantly change the effects of ethanol on migration [32]. These results indicate that alcohol may affect granule cell migration by 


\begin{tabular}{|c|c|c|c|c|c|}
\hline $\begin{array}{l}\text { stimulation } \\
X \text { inhibition }\end{array}$ & $\begin{array}{l}\text { The effects on } \\
\text { rate of granule } \\
\text { cell migratin }\end{array}$ & $\begin{array}{l}\text { The effects on EtOH- } \\
\text { induced impairment of } \\
\text { granule cell migratin }\end{array}$ & $\begin{array}{l}\text { stimulation } \\
\times \text { inhibition }\end{array}$ & $\begin{array}{l}\text { The effects on } \\
\text { rate of granule } \\
\text { cell migratin }\end{array}$ & $\begin{array}{l}\text { The effects on EtOH- } \\
\text { induced impairment of } \\
\text { granule cell migratin }\end{array}$ \\
\hline (NMDA-R) by NMDA & Acceleration & Reduce the effects & GC by ODQ & No effect & Did not alter the effects \\
\hline Rya-R by caffeine & No effect & Reduce the effects & cGMP by $\mathrm{Br}-\mathrm{cGMP}$ & Acceleration & Reduce the effects \\
\hline nAch-R by nicotine & No effect & Amplify the effects & $\begin{array}{l}\text { cGMP by Rp-8-pCPT } \\
\text {-CGMPS }\end{array}$ & Reduction & Did not alter the effects \\
\hline $\mathrm{Ca}^{2+}$ by BAPTA & Reduction & Amplify the effects & PKA by PKI & Acceleration & Reduce the effects \\
\hline PKC by calphostin C & Reduction & Amplify the effects & MAPK) by 00126 & Reduction & Did not alter the effects \\
\hline CaMKII by KN93 & No effect & Did not alter the effects & PI3K by LY294002 & Reduction & Did not alter the effects \\
\hline Rho by H-1152 & Reduction & Amplify the effects & PP1 by tautomycin & Reduction & Did not alter the effects \\
\hline AC by forskolin & Reduction & Amplify the effects & PP2B by deltamethrin & Reduction & Did not alter the effects \\
\hline CAMP by Sp-cAMPS & Reduction & Did not alter the effects & PDE1) by 8-MM-IBMX & No effect & Did not alter the effects \\
\hline CAMP by Rp-cAMPS & Acceleration & Reduce the effects & PDE2 by EHNA & No effect & Reduce the effects \\
\hline
\end{tabular}

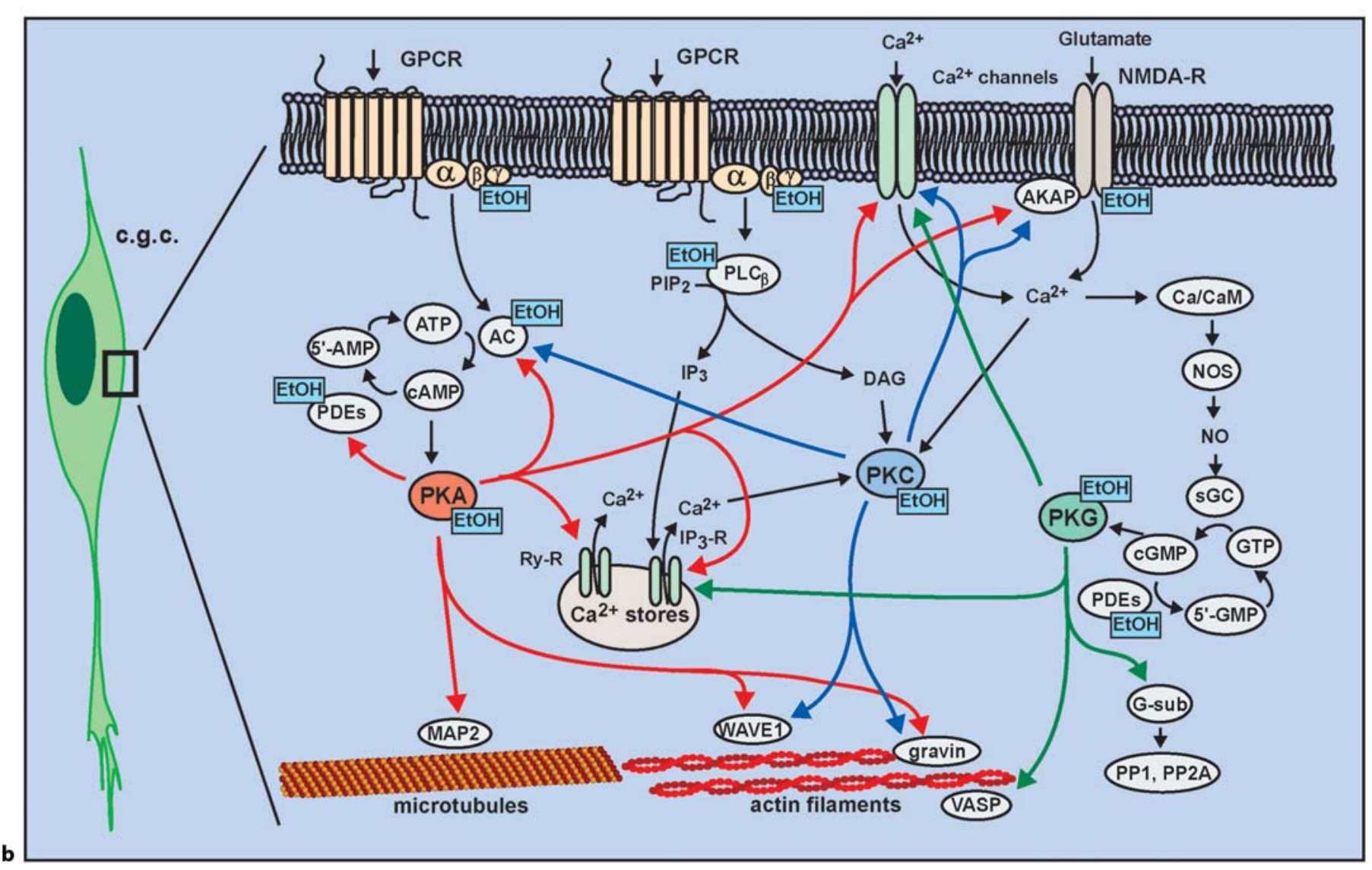


altering the amplitude and duration of cyclic nucleotide signals by modifying the activity of a specific PDE family.

\section{$\mathrm{Ca}^{2+}$-Transient-Dependent and -Independent Mechanisms of the Reversal of Alcohol Action on Migration}

Changes in the frequency of $\mathrm{Ca}^{2+}$ transients positively correlate with changes in the rate of granule cell migration [40,41]. Do caffeine, NMDA, cAMP antagonists, and cGMP agonists reduce alcohol action on granule cell migration by increasing the frequency of $\mathrm{Ca}^{2+}$ transients? The use of a $\mathrm{Ca}^{2+}$ indicator dye reveals that without ethanol, the application of NMDA significantly increases the frequency of $\mathrm{Ca}^{2+}$ transients in migrating granule cells, whereas caffeine does not affect the frequency [32]. Importantly, application of NMDA or caffeine markedly reduces the effects of ethanol on the frequency of $\mathrm{Ca}^{2+}$ transients in granule cells [32]. In the case of cAMP signaling pathways, without ethanol, the stimulation of AC activity with forskolin significantly reduces the frequency of $\mathrm{Ca}^{2+}$ transients, while the inhibition of cAMP signaling with Rp-cAMPS significantly increases the frequency [32]. It is also noteworthy that Rp-cAMPS completely eliminates the effects of ethanol on the frequency of $\mathrm{Ca}^{2+}$ transients [32]. In contrast, neither stimulating cGMP signaling with $\mathrm{Br}$-cGMP nor inhibiting the activity of PDE2 with EHNA changes the effects of ethanol on the frequency of $\mathrm{Ca}^{2+}$ transients [32]. These results indicate that $\mathrm{Ca}^{2+}$ signaling and cAMP signaling may reverse alcohol action on granule cell migration by increasing the frequency of $\mathrm{Ca}^{2+}$ transients in their somata, whereas cGMP signaling and cyclic nucleotide PDE may reduce alcohol action on migration without altering $\mathrm{Ca}^{2+}$ transients.

Fig. 2. Cellular mechanisms underlying alcohol-induced impairment of granule cell migration. a The roles of signaling molecules on granule cell migration and the effects of these molecules on alcohol-induced impairment of granule cell migration are summarized. b Schematic drawing showing the effects of ethanol on the cAMP-PKA, $\mathrm{Ca}^{2+}$-PKC and cGMP-PKG signaling pathway and possible interactions between these signaling pathways in the migrating granule cells. AKAP = A-kinase anchoring proteins; c.g.c. = cerebellar granule cells; GPCR = G-protein-coupled receptors; $\mathrm{NOS}=$ nitric oxide synthase; $\mathrm{NO}=$ nitric oxide; $\mathrm{sGC}=$ soluble guanylyl cyclase.

Alcohol Action on Granule Cell Migration

\section{Requirement of the Activities of Multiple Downstream Targets for Reversing Alcohol Action on Migration by Calcium and Cyclic Nucleotide Signaling}

What downstream effectors are involved in the reversal of alcohol action on granule cell migration by altering $\mathrm{Ca}^{2+}$, cAMP or cGMP signaling? Although these signals interact with large varieties of downstream targets, protein kinase $\mathrm{C}(\mathrm{PKC}), \mathrm{Ca}^{2+} /$ calmodulin-dependent protein kinase II (CaMKII), calcineurin, protein phosphatase 1 (PP1), Rho GTPase, MAPK and phosphoinositide 3-kinase $\left(\mathrm{PI}_{3} \mathrm{~K}\right)$ are chosen as potential targets because these molecules are involved in controlling the motility of various types of cells [126-128]. The use of pharmacological tools reveals that the reversal of alcohol action on granule cell migration by controlling $\mathrm{Ca}^{2+}$, cAMP/cGMP signaling pathways requires the activities of multiple but distinctive downstream effectors: (1) caffeine needs the activities of CaMKII, calcineurin, PP1, Rho GTPase, MAPK and $\mathrm{PI}_{3} \mathrm{~K}$; (2) NMDA needs the activities of PKC, CaMKII, calcineurin, PP1, MAPK and $\mathrm{PI}_{3} \mathrm{~K}$; (3) RpcAMP needs the activities of PKC, CaMKII, calcineurin, PP1, Rho GTPase and $\mathrm{PI}_{3} \mathrm{~K}$, and (4) Br-cGMP needs the activities of PP1, Rho GTPase, MAPK and $\mathrm{PI}_{3} \mathrm{~K}$ [32].

The molecules, receptors and intracellular signaling pathways which are involved in the alcohol-induced impairment of granule cell migration are summarized in figure $2 a, b$.

\section{Elimination of Alcohol Action on Migration in vivo by Controlling Calcium and Cyclic Nucleotide Signaling Pathways}

The effects of alcohol on granule cell migration in vitro are significantly reduced by controlling $\mathrm{Ca}^{2+}$, cAMP and cGMP signaling pathways [32]. Could controlling $\mathrm{Ca}^{2+}$, cAMP and cGMP signaling pathways also reduce the effects of alcohol on granule cell migration in vivo? A single intraperitoneal injection of ethanol $(5 \mathrm{~g} / \mathrm{kg}$ body weight) into P10 mice raises blood ethanol levels to approximately $80 \mathrm{~mm}$ (equivalent to a blood ethanol level $<400 \mathrm{mg} / \mathrm{dl}$ ) within $1 \mathrm{~h}$ after injection, and prevents cerebellar granule cells from entering the ML and slows their radial migration in the ML, PCL and IGL [32]. Importantly, injections of caffeine ( $2 \mathrm{mg} / \mathrm{kg}$ body weight), Rp-cAMPS (0.4 mg/kg body weight) or Br-cGMP (0.4 $\mathrm{mg} / \mathrm{kg}$ body weight) into the subarachnoid space between the skull and the surface of the P10 mouse cerebellum 
with a single intraperitoneal injection of ethanol $(5 \mathrm{~g} / \mathrm{kg}$ body weight) completely reverses the effects of ethanol on granule cell migration in vivo [32]. In contrast, the administration of NMDA ( $>0.01 \mathrm{mg} / \mathrm{kg}$ body weight) into the subarachnoid space between the skull and the surface of the cerebellum often causes the death of injected pups possibly from neurotoxic effects of high doses of NMDA [32]. These results demonstrate that the effects of alcohol on granule cell migration in vivo can be reduced by controlling $\mathrm{Ca}^{2+}$, cAMP and cGMP signaling pathways.

\section{Future Works to Further Understand Neuronal Migration in FAS}

Recent studies suggest the involvement of the $\mathrm{Ca}^{2+}$ PKC, cAMP-PKA and cGMP-PKG signaling pathways in the alcohol-induced impairment of granule cell migration. These 3 signaling pathways interact with each other (schematically shown in fig. 2b). For example, the activity of adenylate cyclase 7 (AC7) is modified by PKC, and alcohol potentiates AC7 activity by altering the activity of PKC $\delta$ [129]. The stimulation of PKA and PKG enhances the activity of voltage-dependent $\mathrm{N}$-type and L-type $\mathrm{Ca}^{2+}$ channels, which in turn affect the $\mathrm{Ca}^{2+}$ signaling pathway $[130,131]$. Activation of the cAMP signaling pathways alters internal $\mathrm{Ca}^{2+}$ release through PKA-mediated phosphorylation of inositol 1,4,5-triphosphate receptors and ryanodine receptors $[132,133]$. Moreover, the activity of PKA regulates NMDA receptor activity through an interaction with A-kinase anchoring protein 79 [134]. Therefore, it may be worth examining whether and how the interactions between the cAMP-PKA, $\mathrm{Ca}^{2+}$ PKC and cGMP-PKG signaling pathways play roles in controlling alcohol action on granule cell migration.

Alcohol also directly and indirectly induces alterations in the activity of other signaling molecules (such as Rho GTPase, MAPK/ERK). There is a functional link between the activity of Rho GTPase and the activities of $\mathrm{Ca}^{2+}$ and PKA signaling. The changes in intracellular $\mathrm{Ca}^{2+}$ levels regulate Rho GTPase activity in various types of cells, although how the changes in $\mathrm{Ca}^{2+}$ levels modulate Rho GTPase activity is essentially unclear [135]. Furthermore, cAMP/PKA is involved in controlling cell migration and cytoskeletal organization via activation of Rho GTPase [136]. Interestingly, alcohol decreases the activity of MAPK/Erk in immature neurons [137]. The reduction of MAPK/Erk activity may be involved in the alcohol-induced impairment of granule cell migration. This is because the reduction of phosphorylated Erk1 and Erk 2 by inhibition of MAPK kinase inhibits neurite outgrowth in cerebellar granule cells [138]. Moreover, PKC and PKA alter the phosphorylation of Erk [139]. Whether alcohol impairs granule cell migration via altering the activity of Rho GTPase and/or MAPK/Erk, remains to be examined.

\section{Conclusion}

In summary, granule cells alter the mode, tempo and direction of migration when they traverse through different cortical layers in the early postnatal brain. These alterations of granule cell migration are controlled by the orchestrated activity of multiple molecules and signaling systems, including $\mathrm{Ca}^{2+}$ channels, NMDA receptors, intracellular $\mathrm{Ca}^{2+}$ fluctuations, BDNF, NRG, SDF-1 $\alpha$, ephrin-B2, EphB2 receptor, astrotactin, tenascin, tPA, PAF, cdk5, 9-O-acetyl GD3 and STT. Furthermore, the internal (intrinsic) programs also play a role in controlling the sequential changes in granule cell migration. In the brains of FAS patients, the migration of immature neurons is severely disrupted. Recent studies suggest that $\mathrm{Ca}^{2+}$ signaling and cyclic nucleotide signaling are the central targets of alcohol action in neuronal migration. Importantly, experimental manipulations of these second-messenger pathways, through stimulating $\mathrm{Ca}^{2+}$ and cGMP signaling or inhibiting cAMP signaling, completely reverse alcohol action on neuronal migration in vitro as well as in vivo. The results suggest that the aberrant migration of immature neurons in the fetal brain caused by maternal alcohol consumption may be corrected by controlling the activity of these second-messenger pathways.

\section{Acknowledgments}

We thank Y. Komuro for critically reading the manuscript. This work was supported by NIH grant AA13613 and Whitehall Foundation Grant 2001-12-35 (to H.K.).

References tion. Experientia 1990;46:882-891.

$\checkmark 2$ Hatten ME, Heintz N: Mechanisms of neural patterning and specification in the developing cerebellum. Annu Rev Neurosci 1995; 18 : 385-408.

-3 Komuro H, Rakic P: Orchestration of neuronal migration by activity of ion channels, neurotransmitter receptors, and intracellular $\mathrm{Ca}^{2+}$ fluctuations. J Neurobiol 1998;37: $110-130$. 
4 Parnavelas JG, Alifragis P, Nadarajah B: The origin and migration of cortical neurons. Prog Brain Res 2002;136:73-80.

5 Nadarajah B, Alifragis P, Wong RO, Parnavelas JG: Neuronal migration in the developing cerebral cortex: observations based on real-time imaging. Cereb Cortex 2003;13: 607-611.

6 Marin O, Rubenstein JL: Cell migration in the forebrain. Annu Rev Neurosci 2003;26: 441-483.

7 Marin O, Rubenstein JL: A long, remarkable journey: tangential migration in the telencephalon. Nat Rev Neurosci 2001;2:780-790.

-8 Metin C, Baudoin JP, Rakic S, Parnavelas JG: Cell and molecular mechanisms involved in the migration of cortical interneurons. Eur J Neurosci 2006;23:894-900.

-9 Flint AC, Kriegstein AR: Mechanisms underlying neuronal migration disorders and epilepsy. Curr Opin Neurol 1997;10:92-97.

$\checkmark 10$ Walsh CA: Genetics of neuronal migration in the cerebral cortex. MRDD Res Rev 2000; 6:34-40.

11 Gleeson JG: Neuronal migration disorders. MRDD Res Rev 2001;7:167-171.

12 Rakic P, Cameron RS, Komuro H: Recognition, adhesion, transmembrane signaling and cell motility in guided neuronal migration. Curr Opin Neurobiol 1994;4:63-69.

$\checkmark 13$ Rakic P, Komuro H: The role of receptor/ channel activity in neuronal cell migration. J Neurobiol 1995;26:299-315.

14 Hatten ME: Central nervous system neuronal migration. Annu Rev Neurosci 1999;22: 511-539.

-15 Yacubova E, Komuro H: Cellular and molecular mechanisms of cerebellar granule cell migration. Cell Biochem Biophys 2003;37: 213-234.

16 Komuro H, Yacubova E: Recent advances in cerebellar granule cell migration. CMLS 2003;60:1084-1098.

17 Hatten ME, Mason CA: Mechanisms of glial-guided neuronal migration in vitro and in vivo. Experientia 1990;46:907-916.

$\checkmark 18$ Komuro H, Kumada T: $\mathrm{Ca}^{2+}$ transients control CNS neuronal migration. Cell Calcium 2005;37:387-393.

19 Rakic P: Neuron-glia relationship during granule cell migration in developing cerebellar cortex: a golgi and electron microscopic study in Macacus rhesus. J Comp Neurol 1971;141:283-312.

20 Rakic P: Mode of cell migration to the superficial layers of fetal monkey neocortex. J Comp Neurol 1972;145:61-83.

21 Grumet M, Hoffman S, Chuong CM, Edelman GM: Polypeptide components and binding functions of neuron-glia cell adhesion molecules. Proc Natl Acad Sci USA 1984;181:7989-7993.

-22 Hoffman S, Friedlander DR, Chuong CM, Grumet M, Edelman GM: Differential contribution of Ng-CAM and N-CAM to cell adhesion in different neural regions. J Cell Biol 1986;103:145-158.
23 Chuong CM, Crossin KL, Edelman GM: Sequential expression and differential function of multiple adhesion molecules during the formation of cerebellar cortical layers. J Cell Biol 1987;104:331-342.

24 Edmondson JC, Liem RKH, Kuster JE, Hatten ME: Astrotactin: a novel neuronal cell surface antigen that mediates neuron-astroglial interactions in cerebellar microcultures. J Cell Biol 1988;106:505-517.

25 Komuro H, Rakic P: Modulation of neuronal migration by NMDA receptors. Science 1993;260:95-97.

26 BeharTN, Schaffner AE, ScottCA, O’Connell C, Barker JL: Differential response of cortical plate and ventricular zone cells to GABA as a migration stimulus. J Neurosci 1998;18: 6378-6387.

- 27 Behar TN, Scott CA, Greene CL, Wen X, Smith SV, Maric D, Liu QY, Colton CA, Barker JL: Glutamate acting at NMDA receptors stimulates embryonic cortical neuronal migration. J Neurosci 1999;19:4449-4461.

-28 Hirai K, Yoshida H, Kihara M, Hasegawa K, Sakamoto T, Sawada T, Fushiki S: Inhibiting neuronal migration by blocking NMDA receptors in the embryonic rat cerebral cortex: a tissue culture study. Brain Res Dev Brain Res 1999;114:63-67.

29 Komuro H, Rakic P: Dynamics of granule cell migration: a confocal microscopic study in acute cerebellar slice preparations. J Neurosci 1995;15:1110-1120.

30 Komuro H, Rakic P: Distinct modes of neuronal migration in different domains of developing cerebellar cortex. J Neurosci 1998; 18:1478-1490.

31 Komuro H, Yacubova E, Yacubova E, Rakic $\mathrm{P}$ : Mode and tempo of tangential cell migration in the cerebellar external granular layer. J Neurosci 2001;21:527-540.

32 Kumada T, Lakshmana ML, Komuro H: Reversal of neuronal migration in a mouse model of fetal alcohol syndrome by controlling second-messenger signalings. J Neurosci 2006;26:742-756.

33 Fujita S: Quantitative analysis of cell proliferation and differentiation in the cortex of the postnatal mouse cerebellum. J Cell Biol 1967;32:277-287.

34 Uzman L: The development of neonatal mouse cerebellum studied by tritiated thymidine uptake. J Comp Neurol 1960;114: 137-159.

35 Miale IL, Sidman RL: An autoradiographic analysis of histogenesis in the mouse cerebellum. Exp Neurol 1961;4:277-296.

36 Fujita S, Shimada M, Nakamura T: $\mathrm{H}^{3}$-thymidine autoradiographic studies on the cell proliferation and differentiation in the external and the internal granular layers of the mouse cerebellum. J Comp Neurol 1966;128: 191-208.

37 Ryder EF, Cepko CL: Migration patterns of clonally related granule cells and their progenitors in the developing chick cerebellum. Neuron 1994;12:1011-1028.
38 Yacubova E, Komuro H: Intrinsic program for migration of cerebellar granule cells in vitro. J Neurosci 2002;22:5966-5981.

-39 Komuro H, Rakic P: Selective role of N-type calcium channels in neuronal migration. Science 1992;257:806-809.

40 Komuro H, Rakic P: Intracellular $\mathrm{Ca}^{2+}$ fluctuations modulate the rate of neuronal migration. Neuron 1996;17:275-285.

41 Kumada T, Komuro H: Completion of neuronal migration regulated by loss of $\mathrm{Ca}^{2+}$ transients. Proc Natl Acad Sci USA 2004;101: 8479-8484.

42 Rossi D, Slater TN: The developmental onset of NMDA receptor channel activity during neuronal migration. Neuropharmacology 1993;32:1239-1248.

-43 Farrant M, Feldmeyer D, Takahashi T, CullCandy SG: NMDA-receptor channel diversity in the developing cerebellum. Nature 1994;368:335-339.

44 Monyer H, Burnashev N, Lauria DJ, Sakman B, Seeburg PH: Development of regional expression in the rat brain and functional properties of four NMDA receptors. Neuron 1994;12:529-540.

45 Rocamora N, Garcia LF, Palacios JM, Mengod G: Differential expression of brain-derived neurotrophic factor, neurotrophin-3, and low-affinity nerve growth factor receptor during the postnatal development of the rat cerebellar system. Brain Res Mol Brain Res 1993;17:1-8.

46 Segal R, Pomeroy S, Stiles C: Axonal growth and fasciculation linked to differential expression of BDNF and NT3 receptors in developing cerebellar granule cells. J Neurosci 1995;15:4970-4981.

47 Borghesani PR, Peyrin JM, Klein R, Rubin J, Carter AR, Schwartz PM, Luster A, Corfas G Segal RA: BDNF stimulates migration of cerebellar granule cells. Development 2002;129: 1435-1442.

48 Ernfors P, Merlio JP, Persson H: Cells expressing mRNA for neurotrophins and their receptors during embryonic rat development. Eur J Neurosci 1992;4:1140-1158.

49 Neveu I, Arenas B: Neurotrophins promote the survival and development of neurons in the cerebellum of hypothyroid rats in vivo. J Cell Biol 1996;133:631-646.

50 Lindholm D, Castren E, Tsoulfas P, Kolbeck R, Berzaghi MDP, Leingartner A, Heisenberg CP, Tessarollo L, Parada LF, Thoenen H: Neurotrophin-3 induced tri-iodothyronine in cerebellar granule cells promotes Purkinje cell differentiation. J Cell Biol 1993;122: 443-450.

51 Doughty ML, Lohof A, Campana A, Delhaye-Bouchaud N, Mariani J: Neurotrophin3 promotes cerebellar granule cell exit from the EGL. Eur J Neurosci 1998; 10:3007-3011.

52 Rio C, Rieff HI, Qi P, Khurana TS, Corfas G: Neuregulin and erbB receptors play a critical role in neuronal migration. Neuron 1997;19: $39-50$. 
-53 Zou YR, Kottmann AH, Kuroda M, Taniuchi I, Littman DR: Function of the chemokine receptor CXCR4 in haematopoiesis and in cerebellar development. Nature 1998;393: 595-599.

54 McGrath K, Koniski AD, Maltby KM, McGann JK, Palis J: Embryonic expression and function of the chemokine SDF-1 and its receptor, CXCR4. Dev Biol 1999;213:442-456.

-55 Ma Q, Jones D, Borghesani PR, Segal RA, Nagasawa T, Kishimoto T, Bronson RT, Springer TA: Impaired B-lymphopoiesis, myelopoiesis, and derailed cerebellar neuron migration in CXCR4- and SDF-1-deficient mice. Proc Natl Acad Sci USA 1998;95:94489453.

- 56 Klein RS, Rubin JB, Gibson HD, DeHaan EN, Alvarez-Hernandez X, Segal RA, Luster AD: SDF- $1 \alpha$ induces chemotaxis and enhances Sonic hedgehog-induced proliferation of cerebellar granule cells. Development 2001;128:1971-1981.

-57 Lu Q, Sun EE, Klein RS, Flanagan JG: Ephrin-B reverse signaling is mediated by a novel PDZ-RGS protein and selectively inhibits $\mathrm{G}$ protein-coupled chemoattraction. Cell 2001;105:69-79.

58 Adams NC, Tomoda T, Cooper M, Dietz G, Hatten ME: Mice that lack astrotactin have slowed neuronal migration. Development 2002;129:965-972.

59 Husmann K, Faissner A, Schachner M: Tenascin promotes cerebellar granule cell migration and neurite outgrowth by different domains in the fibronectin type III repeats. J Cell Biol 1992;116:1475-1486.

60 Friedman GC, Seeds NW: Tissue plasminogen activator mRNA expression in granule neurons coincides with their migration in the developing cerebellum. J Comp Neurol 1995;360:658-670.

61 Verrall S, Seeds NW: Characterization of ${ }^{125}$ I-tissue plasminogen activator binding to cerebellar granule neurons. J Cell Biol 1989; 109:265-271.

-62 Seeds NW, Basham ME, Haffke SP: Neuronal migration is retarded in mice lacking the tissue plasminogen activator gene. Proc Nat Acad Sci USA 1999;96:14118-14123.

63 Stewart RM, Richman DP, Caviness VSJ: Lissencephaly and pachygyria: an architectonic and topographic analysis. Acta Neuropathol 1975;31:1-12.

64 Jellinger K, Rett A: Agyria-pachygyria (lissencephaly syndrome). Neuropediatrics 1976;7:6691.

65 Miller J: Lissencephaly in two siblings. Neurology 1963;13:841-850.

- 66 Reiner O, Albrecht U, Gordon M, Chianese KA, Wong C, Gal-Gerber O, Sapir T, Siracusa LD, Buchberg AM, Caskey CT: Lissencephaly gene (LIS1) expression in the CNS suggests a role in neuronal migration. J Neurosci 1995; 15:3730-3738.
67 Hattori M, Arai H, Inoue K: Purification and characterization of bovine brain platelet-activating factor acetylhydrolase. J Biol Chem 1993;268:18748-18753.

68 Hattori M, Hideki A, Tsujimoto M, Arai H, Inoue $\mathrm{K}$ : Catalytic subunit of bovine brain platelet-activating factor acetylhydrolase is a novel type of serine esterase. J Biol Chem 1994;269:23150-23155.

69 Clark GD, McNeil RS, Bix GJ, Swann JW: Platelet-activating factor produces neuronal growth cone collapse. Neuroreport 1995;6: 2569-2575.

70 Bix GJ, Clark GD: Platelet-activating factor receptor stimulation disrupts neuronal migration in vitro. J Neurosci 1998; 18:307318.

71 Sherr CJ: Mammalian G1 cyclins. Cell 1993; 73:1059-1065.

72 Tsai L-H, Takahashi T, Caviness VSJ, Harlow E: Activity and expression pattern of cyclindependent kinase-5 in the embryonic mouse central nervous system. Development 1993; 119:1029-1040.

73 Ohshima T, Gilmore EC, Longenecker G, Jacobowitz DM, Brady RO, Herrup K, Kulkarni AB: Migration defects of $c d k 5^{-/-}$neurons in the developing cerebellum is cell autonomous. J Neurosci 1999;19:6017-6026.

74 Santiago MF, Berredo-Pinho M, Costa MR, Gandra M, Cavalcante LA, Mendez-Otero R: Expression and function of ganglioside 9-Oacetyl GD3 in postmitotic granule cell development. Mol Cell Neurosci 2001;17:488499.

-75 Schindler M, Humphrey PPA, Emson PC: Somatostatin receptors in the central nervous system. Prog Neurobiol 1996;50:9-47.

76 Patel YC: Molecular pharmacology of somatostatin receptor subtypes. J Endocrinol In vest 1997;20:348-367.

77 Viollet C, Bodenant C, Prunotto C, Roosterman D, Schaefer J, Meyerhof W, Epelbaum J, Vaudry H, Leroux P: Differential expression of multiple somatostatin receptors in rat cerebellum during development. J Neurochem 1997;68:2263-2272.

78 Naus CCG: Developmental appearance of somatostatin in the rat cerebellum: in situ hybridization and immunohistochemistry. Brain Res Bul 1990;24:583-592.

79 Yacubova E, Komuro H: Stage-specific control of neuronal migration by somatostatin. Nature 2002;415:77-81.

80 Deo DD, Bazan NG, Hunt JD: Activation of platelet-activating factor receptor-coupled $\mathrm{G} \alpha_{\mathrm{q}}$ leads to stimulation of Src and focal adhesion kinase via two separate pathways in human umbilical vein endothelial cells. J Biol Chem 2004;279:3497-3508.

81 Princen K, Hatse S, Vermeire K, De Clercq E, Schols D: Evaluation of SDF-1/CXCR4-induced $\mathrm{Ca}^{2+}$ signaling by fluorometric imaging plate reader (FLIP) and flow cytometry. Cytometry 2003;51:35-45.
82 Roland J, Murphy BJ, Ahr B, Robert-Hebmann V, Delauzun V, Nye KE: Role of the intracellular domains of CXCR4 in SDF-1mediated signaling. Blood 2003;101:399_ 406.

83 Fernandez-Monreal M, Lopez-Atalaya JP, Benchenane K, Leveille F, Cacquevel M, Plawinski L, MacKenzie ET, Bu G, Buisson A, Vivien D: Is tissue-type plasminogen activator a neuromodulator? Mol Cell Neurosci 2004;25:594-601.

84 Pantazis NJ, West JR, Dai D: The nitric oxide-cyclic GMP pathway plays an essential role in both promoting cell survival of cerebellar granule cells in culture and protecting the cells against ethanol neurotoxicity. J Neurochem 1998;70:1826-1838.

85 Tentler JJ, Hadcock JR, Gutierrez-Hartmann A: Somatostatin acts by inhibiting the cyclic 3',5'-adenosine monophosphate (cAMP)/ protein kinase A pathway, cAMP response element-binding protein (CREB) phosphorylation, and CREB transcription potency. Mol Endocrinol 1997;11:859-866.

\$86 Gunn-Moore F, Williams AG, Tavare JM: Analysis of mitogen-activated protein kinase activation by naturally occurring splice variants of TrkC, the receptor for neurotrophin-3. Biochem J 1997;322:193-198.

87 Yuen EC, Mobley WC: Early BDNF, NT-3, and NT-4 signaling events. Exp Neurol 1999; 159:297-308.

88 Du Y, Lercher LD, Zhou R, Dreyfus CF: Mitogen-activated protein kinase pathway meditates effects of brain-derived neurotrophic factor on differentiation of basal forebrain oligodendrocytes. J Neurosci Res 2006;84:1692-1702.

89 Pareek TK, Kulkarni AB: Cdk5: a new player in pain signaling. Cell Cycle 2006;5:585588 .

90 Clarren SK, Smith DW: The fetal alcohol syndrome. N Engl J Med 1978;298:10631067.

91 Clarren SK, Alvord EC, Sumi SM: Brain malformations related to prenatal exposure to ethanol. J Pediatr 1978;92:64-67.

92 Marcus JC: Neurological findings in the fetal alcohol syndrome. Neuropediatrics 1987:18: 158-160.

93 Jones KL, Smith DW: Recognition of the fetal alcohol syndrome in early infancy. Lancet 1973;2:999-1001.

94 Committee on Substace Abuse: Fetal alcohol syndrome and fetal alcohol effects. Pediatrics 1993;91:1004-1006.

95 Clarren SK, Astley SJ, Bowden DM, Lai H, Milam AH, Rudeen PK, Shoemaker WJ: Neuroanatomic and neurochemical abnormalities in nonhuman primate infants exposed to weekly dose of ethanol during gestation. Alcohol Clin Exp Res 1990;14: 674-683.

96 Wisniewski K, Damabska M, Sher JH, Qazi Q: A clinical neuropathological study of the fetal alcohol syndrome. Neuropediatrics 1983; 14:197-205. 
97 Coffin JM, Baroody S, Schneider K, O’Neill $\mathrm{J}$ : Impaired cerebellar learning in children with prenatal alcohol exposure: a comparative study of eyeblink conditioning in children with ADHD and dyslexia. Cortex 2005;41:389-398.

98 Manzardo AM, Penick EC, Knop J, Nickel EJ, Hall S, Jensen P, Gabrielli WF Jr: Developmental differences in childhood motor coordination predict adult alcohol dependence: proposed role for the cerebellum in alcoholism. Alcohol Clin Exp Res 2005;29: 353-357.

99 Costa LG, Vitalone A, Guizzetti M: Signal transduction mechanisms involved in the antiproliferative effects of ethanol in glial cells. Toxicol Lett 2004;149:67-73.

100 Olney JW: Fetal alcohol syndrome at the cellular level. Addict Biol 2004;9:137-149.

101 West JR, Chen WJ, Pantazis NJ: Fetal alcohol syndrome: the vulnerability of the developing brain and possible mechanisms of damage. Metab Brain Dis 1994;9:291-322.

102 Kennedy LA: The pathogenesis of brain abnormalities in the fetal alcohol syndrome: an integrating hypothesis. Teratology 1984; 29:363-368.

103 Guerri C: Mechanisms involved in central nervous system dysfunctions induced by prenatal ethanol exposure. Neurotox Res 2002;4:327-335.

104 Miller MW: Effects of alcohol on the generation and migration of cerebral cortical neurons. Science 1986;233:1308-1311.

105 Miller MW: Migration of cortical neurons is altered by gestational exposure to ethanol. Alcohol Clin Exp Res 1993;17:304314.

106 Peiffer J, Majewski F, Fischbach H, Bierich JR, Volk B: Alcohol embryo and fetopathy. J Neurol Sci 1979;41:125-137.

107 Coulter CL, Leech RW, Schaefer GB, Scheithauer BW, Brumback RA: Midline cerebral dysgenesis, dysfunction of the hypothalamic-pituitary axis, and fetal alcohol effects. Arch Neurol 1993;50:771-775.

108 Dikranian K, Qin YQ, Labruyere J, Nemmers B, Olney JW: Ethanol-induced neuroapoptosis in the developing rodent cerebellum and related brain stem structures. Dev Brain Res 2005;155:1-13.

-109 Sakata-Haga H, Sawada K, Hisano S, Fukui Y: Abnormalities of cerebellar foliation in rats prenatally exposed to ethanol. Acta Neuropathol 2001;102:36-40.

-110 Kornguth SE, Rutledge JJ, Sunderland E, Siegel F, Carlson I, Smollens J, Juhl U, Young B: Impeded cerebellar development and reduced serum thyroxine levels associated with fetal alcohol intoxication. Brain Res 1979;177:347-360.

- 111 Bauer-Moffet C, Altman J: Ethanol-induced reductions in cerebellar growth of infant rats. Expl Neurol 1975;48:378-382.
12 Borges S, Lewis PD: Effects of ethanol on postnatal cell acquisition in the rat cerebellum. Brain Res 1983;271:388-391.

113 Kotkoskie LA, Norton S: Prenatal brain malformations following acute ethanol exposure in the rat. Alcohol Clin Exp Res 1988;12:831-836.

114 Siegenthaler JA, Miller MW: Transforming growth factor $\beta 1$ modulates cell migration in rat cortex: effects of ethanol. Cerebral Cortex 2004;14:791-802.

115 Panicker AK, Buhusi M, Thelen K, Maness PF: Cellular signaling mechanisms of neural cell adhesion molecules. Front Biosci 2003;8:d900-d911.

116 Charness ME, Safran RM, Perides G: Ethanol inhibits neural cell-cell adhesion. J Biol Chem 1994;269:9304-9309.

117 Miller MW, Luo J: Effects of ethanol and transforming growth factor $\beta$ (TGF $\beta$ ) on neuronal proliferation and $\mathrm{nCAM}$ expression. Alcohol Clin Exp Res 2002;26:12811285.

118 Bauer-Moffet C, Altman J: The effect of ethanol chronically administrated to preweanling rats on cerebellar development: a morphological study. Brain Res 1977;119: 249-268.

119 Jones DG: Influence of ethanol on neuronal and synaptic maturation in the central nervous system - morphological investigations. Prog Neurobiol 1988;31:171-197.

120 West JR, Chen WJ, Pantazis NJ: Fetal alcohol syndrome: the vulnerability of the developing brain and possible mechanisms of damage. Metab Brain Dis 1994;9:291-322.

121 Shetty AK, Phillips DE: Effects of prenatal ethanol exposure on the development of Bergmann glia and astrocytes in the rat cerebellum: an immunohistochemical study. J Comp Neurol 1992;321:19-32.

122 Peoples RW, Li C, Weight FF: Lipid versus protein theories of alcohol action in the nervous system. Annu Rev Pharmacol Toxicol 1996;36:185-201.

123 Walter HJ, Messing RO: Regulation of neuronal voltage-gated calcium channels by ethanol. Neurochem Int 1999;35:95-101.

124 Lovinger DM, White G, Weight FF: Ethanol inhibits NMDA-activated ion current in hippocampal neurons. Science 1989;243: 1721-1724.

125 Mezna M, Patchick T, Tovey S, Michelangeli F: Inhibition of the cerebellar inositol 1,4,5-trisphosphate-sensitive $\mathrm{Ca}^{2+}$ channel by ethanol and other aliphatic alcohols. Biochem J 1996;314:175-179.

126 Yang S, Huang XY: $\mathrm{Ca}^{2+}$ influx through Ltype $\mathrm{Ca}^{2+}$ channels controls the trailing tail contraction in growth factor-induced fibroblast cell migration. J Biol Chem 2005; 280:27130-27137.
27 Titus B, Schwartz MA, Theodorescu D Rho proteins in cell migration and metastasis. Crit Rev Eukaryot Gene Expr 2005; 15 103-114.

128 Rajalingam K, Wunder C, Brinkmann V, Churin Y, Hekman M, Sievers C, Rapp UR, Rudel T: Prohibition is required for Ras-induced Raf-MEK-ERK activation and epithelial cell migration. Nat Cell Biol 2005;7: 837-843.

129 Tabakoff B, Nelson E, Yoshimura M, Hellevuo K, Hoffman PL: Phosphorylation cascades control the actions of ethanol on cell cAMP signaling. J Biomed Sci 2001;8:4451.

130 Maeno-Hikichi Y, Chang S, Matsumura K, Lai M, Lin H, Nakagawa N, Kuroda S, Zhang JF: A PKC epsilon-ENH-channel complex specifically modulates N-type $\mathrm{Ca}^{2+}$ channels. Nat Neurosci 2003;6:468475.

-131 Zsombok A, Schrofner S, Hermann A, Kerschbaum HH: A cGMP-dependent cascade enhances an L-type-like $\mathrm{Ca}^{2+}$ current in identified snail neurons. Brain Res 2005 1032:70-76.

132 Straub SV, Wagner LE 2nd, Bruce JI, Yule DI: Modulation of cytosolic calcium signaling by protein kinase A-mediated phosphorylation of inositol 1,4,5-triphosphate receptors. Biol Res 2004;37:593-602.

133 Tasken K, Aandahl EM: Localized effects of cAMP mediated by distinct routes of protein kinase A. Physiol Rev 2004;84:137167.

134 Gomez LL, Alam S, Smith KE, Horne E, Dell'Acqua ML: Regulation of A-kinase anchoring protein 79/150 cAMP-dependent protein kinase postsynaptic targeting by NMDA receptor activation of calcineurin and remodeling of dendritic actin. J Neurosci 2002;22:7027-7044.

135 Price LS, Langeslag M, ten Klooster JP, Hordijk PL, Jalink K, Collard, JG: Calcium signaling regulates translocation and activation of Rac. J Biol Chem 2003;278:3941339421.

136 Howe AK: Regulation of actin-based cell migration by cAMP/PKA. Biochem Biophys Acta 2004;1692:159-174.

-137 Tsuji R, Guizzetti M, Costa LG: In vivo ethanol decreases phosphorylated MAPK and p70S6 kinase in the developing rat brain. Neuroreport 2003;14:1395-1399.

-138 Tang N, He M, O'Riordan MA, Farkas C Buck K, Lemmon V, Bearer CF: Ethanol inhibits L1 cell adhesion molecule activation of mitogen-activated protein kinases. J Neurochem 2006;96:1480-1490.

139 Segal RA, Greenberg ME: Intracellular signaling pathway activated by neurotrophic factors. Annu Rev Neurosci 1996:19:463489. 